\title{
Strategic Planning Model for Private Hospitals with Delphi Method: a Study in Khatam Alanbia Hospital
}

\author{
Hassan Darvish ${ }^{1}$, Pirhossein Kolivand ${ }^{1,2^{*}}$, Reza Rasouli ${ }^{1}$, Hasan Mobaraki ${ }^{1}$ \\ ${ }^{1}$ Public Administration Department, Higher Education Center, Payame Noor University, Tehran, Iran. \\ ${ }^{2}$ Shefa Neuroscience Research Center, Khatam Alanbia Hospital, Tehran, Iran.
}

\section{A BSTRACT}

Introduction: Nowadays, in the changeable environment, the organizations try to achieve the long-term purposes by the strategic planning process. This process usually is begun with an analysis of internal and external environmental factors and will be terminated with a well-organized implementation and assessment. Since, all the missions, purposes, opportunities, threats, strengths, and weakness of each organization are different with others, the components in the planning of the process and strategy should be determined individually for each organization. The present study was aimed to design and develop a strategic planning model for Khatam Alanbia Hospital. Materials and Methods: To achieve the mentioned objectives, Delphi technique, a qualitative method, has been selected to perform the investigation. Delphi's group is consisted of 20 experts in the field of strategic planning, managers, and supervisors of Tehran's private hospitals. Results: The final model of strategic planning for Khatam Alanbia Hospital with 12 components was designed after 4 Delphi rounds. The most remarkable points of the new model are adding two components of balanced scorecard and designing the strategic map in order to link between strategy development and implementation. Conclusion: This model facilitates and accelerates the achievement of the objectives of a strategic plan in private hospitals.

\section{Key words:}

1. Strategic Planning

2. Delphi Method

3. Environmental Factors

Analysis

4. Strategy Development

5. Balanced Scorecard

* Corresponding Author: Pirhossein Kolivand

E-mail: peirhossein@yahoo.com 


\title{
طراحى مدل برنامه ريزى استراتزيكى بيمارستانهاى خصوصى به كمك روش دلفى: يك مورد مطالعه در بيمارستان خاتم الانبياء
}

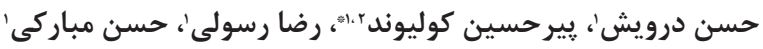 \\ ' لمروه مديريت دولتى، مركز آموزش عالى، دانشخاه بيام نور، تمران، ايران.

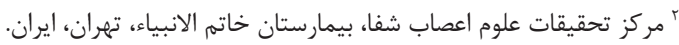

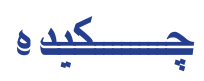

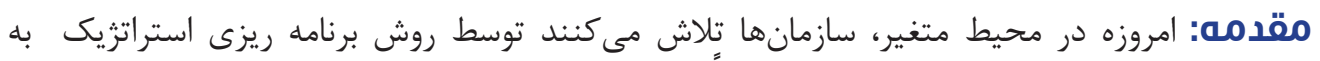

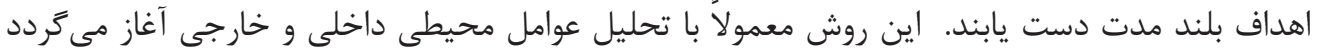

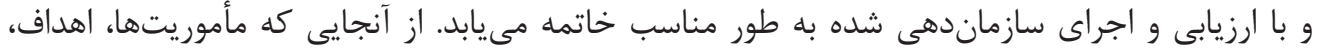

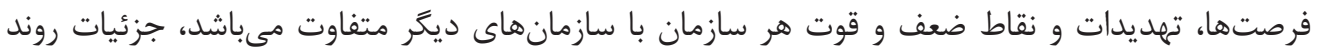

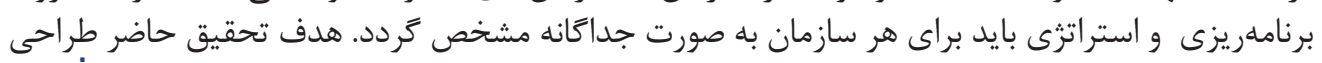

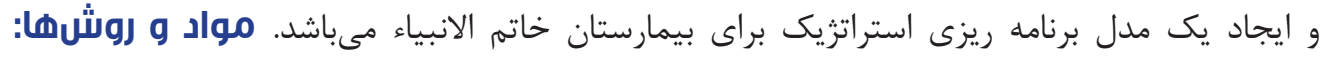

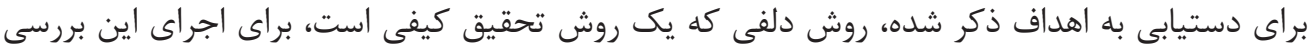

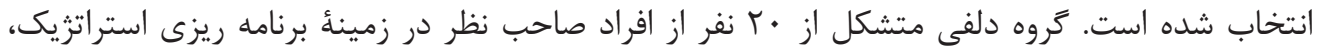

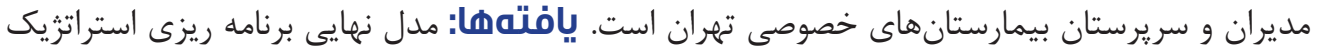

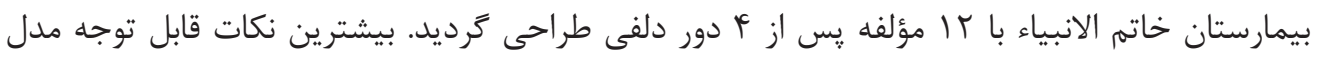

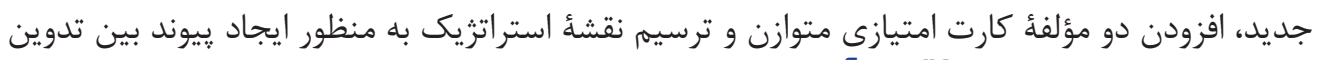

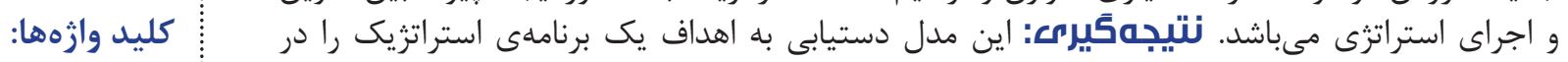
1. ا. برنامه ريزى استراتزيك بيمارستان هاى خصوصى تسهيل مى كند.

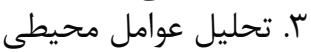

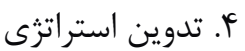

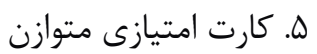


متغير آكاه باشند (1). امروزه در برنامه ريزى استراتزيكى بايد

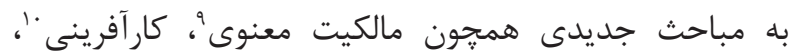

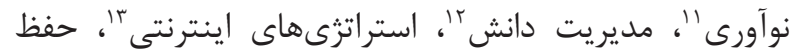

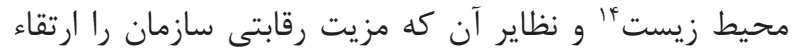

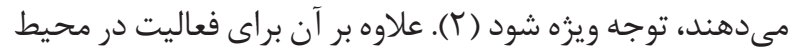

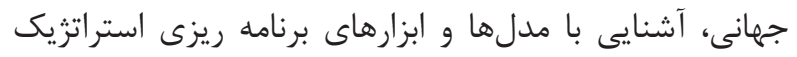

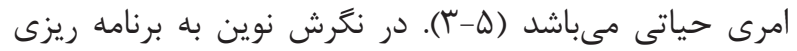

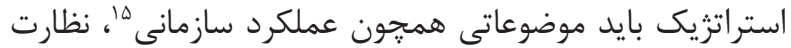

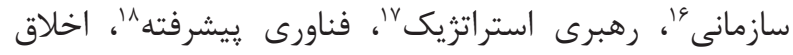

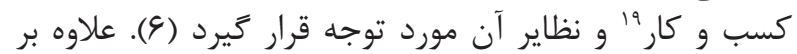

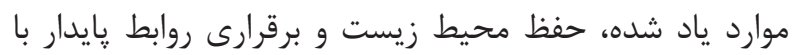

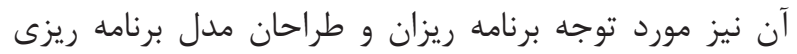

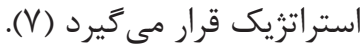

در مطالعات جديد استراتزيك، مباحثى نظير استراتثى هستهاى،

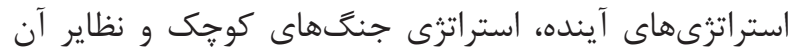

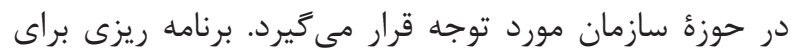

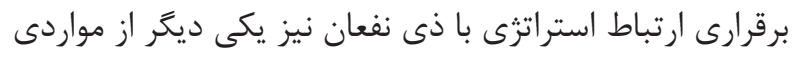

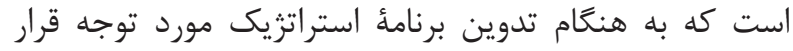

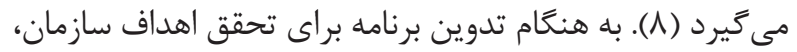

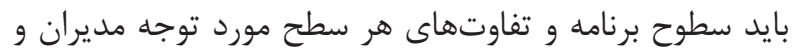
برنامه ريزان قرار زيرد.

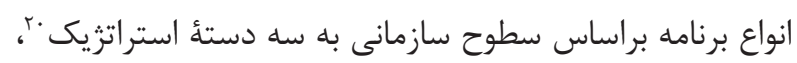

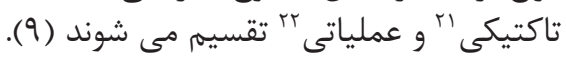

• الف - استراتزيك: عبارت است از تعيين اهداف بلندمدت

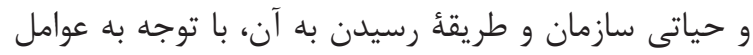
محيطى و با درنظر كرفتن آينده سازمان رسيد بهن

• ب- تاكتيكى: عبارت است از اتخاذ تصميمهاى كوتاه

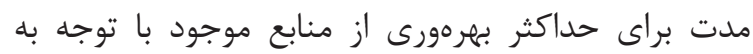

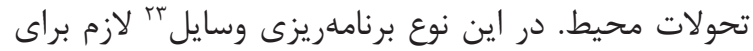

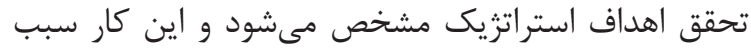

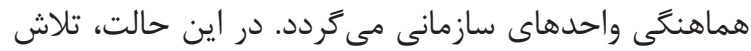

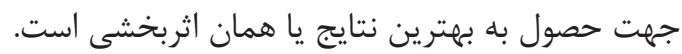

• ج - عملياتى: عبارت است از تعيين عمليات (فعاليتهاى)

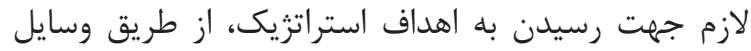

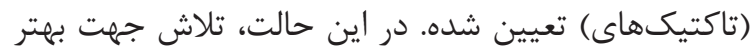
انجام دادن كارها يا همان كارايى مى تعبين داشد.

اين سه نوع برنامه در جدول شماره ا با هم مقايسه شدهاند.

${ }^{1}$ Strategic planning

${ }^{2}$ Analysis of environmental factors

${ }^{3}$ Mission

${ }^{4}$ Vision

${ }^{5}$ Balanced scorecard

${ }^{6}$ Delphi method

${ }^{7}$ Business

${ }^{8}$ Competitive advantage

${ }^{9}$ Intellectval properties

${ }^{10}$ Entre prenurship

${ }^{11}$ Innovation

${ }^{12}$ Knowledge management

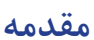

برنامه ريزى استراتزيك' يكى از وظايف مهلم مديران ارشد

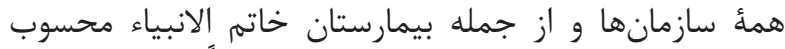

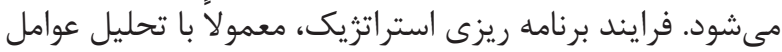

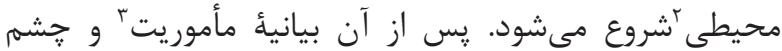

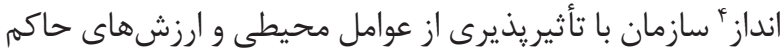

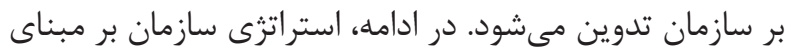

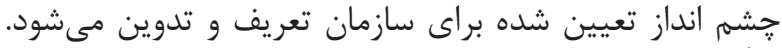

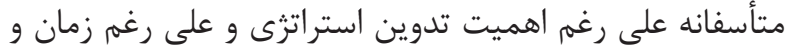

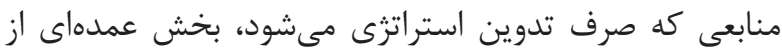

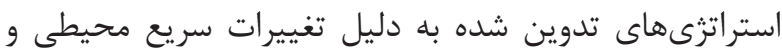

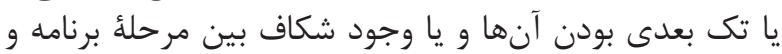

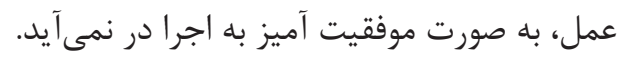

به هنگَام طراحى مدل برنامه ريزى استراتزيك، حركت به سمت

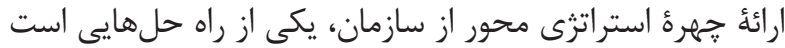

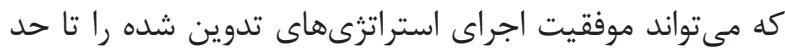

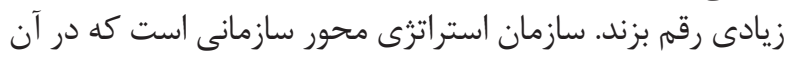

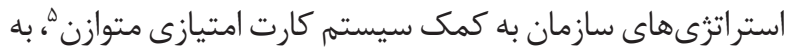

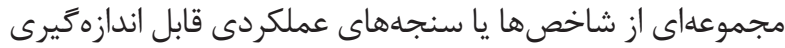

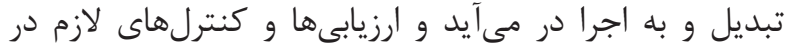

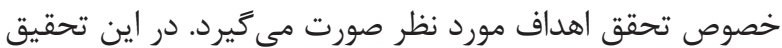

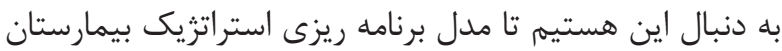

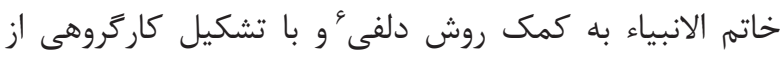

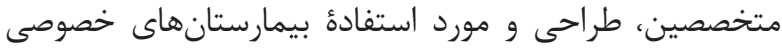

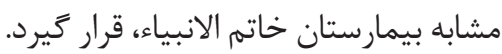

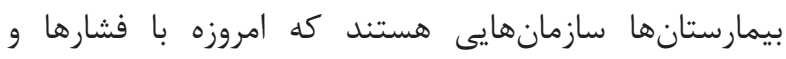

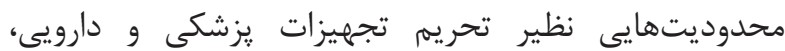

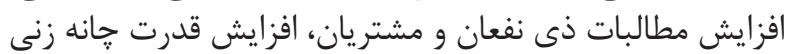

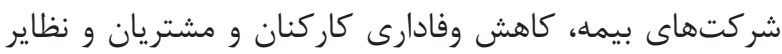

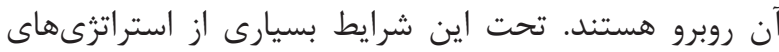

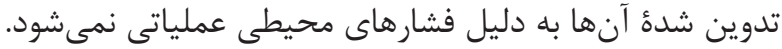

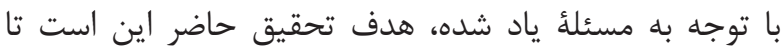

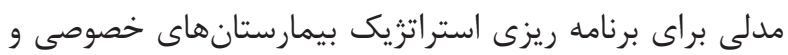

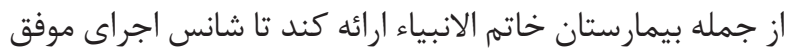

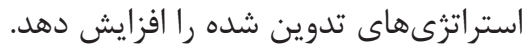

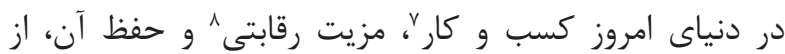

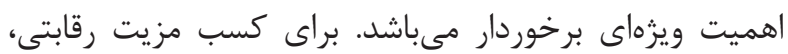

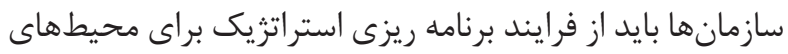

\footnotetext{
${ }^{13}$ Internet strategy

${ }^{14}$ Environmental protection

${ }^{15}$ Organizational performance

${ }^{16}$ Organizational oversight

${ }^{17}$ Strategic leadership

${ }^{18}$ Advanced technology

${ }^{19}$ Business ethic

${ }^{20}$ Strategic

${ }^{21}$ Tactical

22 Operational

${ }^{23}$ Means
} 
جدول ا- مقايسه برنامههاى استراتزيك، تاكتيكى و عملياتى (9).

\begin{tabular}{|c|c|c|c|}
\hline عملياتى & تاكتيكى & استراتريك & 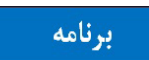 \\
\hline تعيين فعاليتها، كار آيى، منفع & تعيين وسايل اثربخشى & تعيين اهداف عالى، بهردورى، & هدف \\
\hline نظارت فنى & هماهنكى واحدها: & هدايت تمام سازمان & 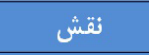 \\
\hline حداكثر اسال & حداكثر r سال & r r-r & زمان \\
\hline ندارد & متوسط & خيلى زياد & توجه به محيط \\
\hline مديريت اجرايى & مديريت ميانى & مديريت عالى & سطح سازمائى \\
\hline
\end{tabular}

مرحلة جهارم به بازنترى در ميزان اهميت عوامل بر اساس نتايج

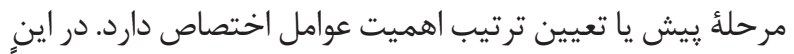

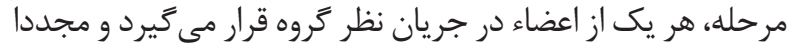

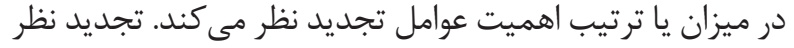

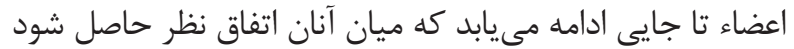
يا تعداد شركت كنندكان به كمتر از حان حد لازم برسد.

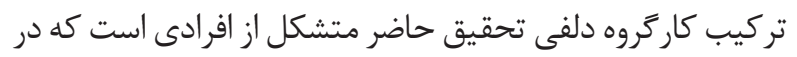

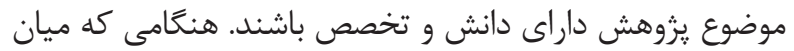

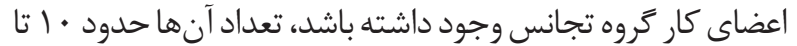

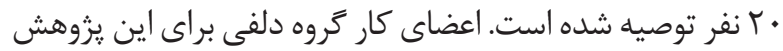

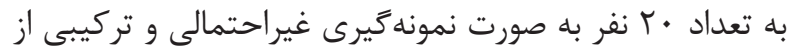

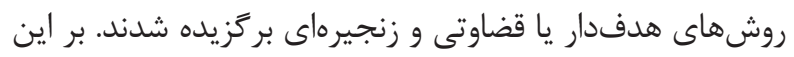

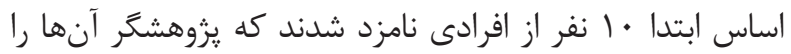

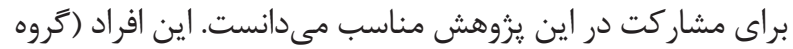
اول) واجد يك يا جند ويزّكى زير بودند: الف. عضو هيئت علمى دانشخاه و صاحب نظر در زمينهُ مديريت

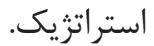

ب. مدير يا سريرست بخشهاى مختلف بيمارستان.

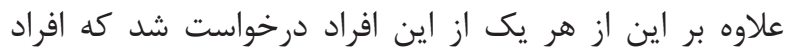

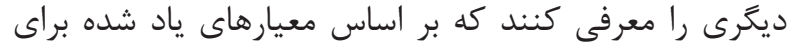

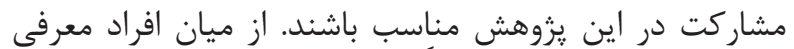

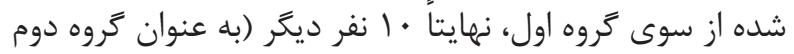

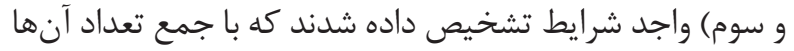

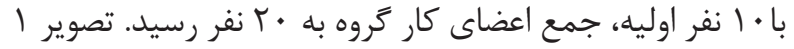

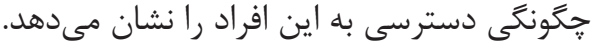

مواد و روشها

روش دلفى يكى از روشهاى تحقيق كيفى است كه از آن بـ به به

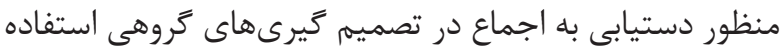

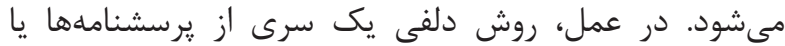

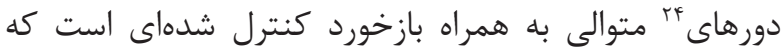

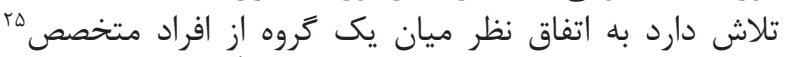

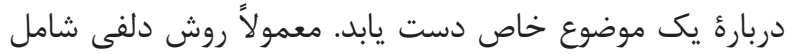
مراحل اساسى زير مىباشد (• (1):

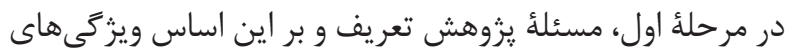

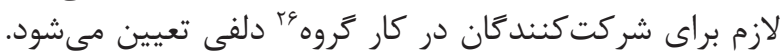

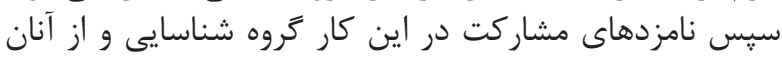

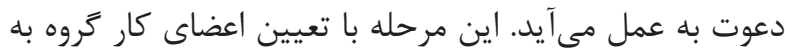

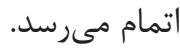

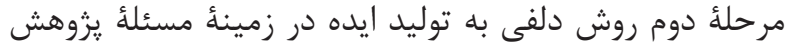

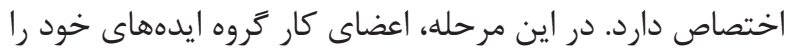

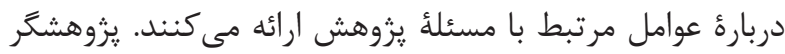

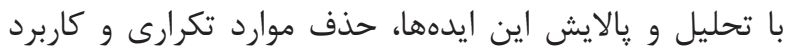

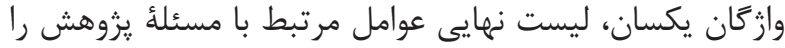

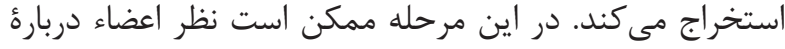
عواملى خواسته شود كه از بِيش تعيين شدهاند.

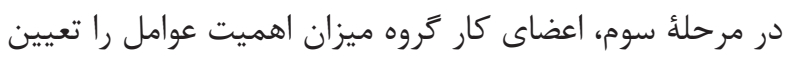

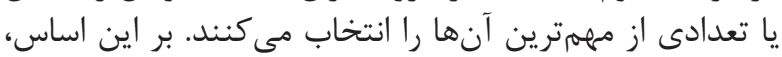

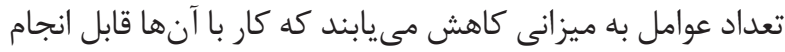

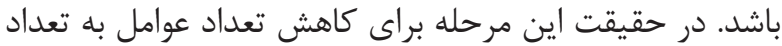
قابل قبول براى ادامة كار انجام مىشود.

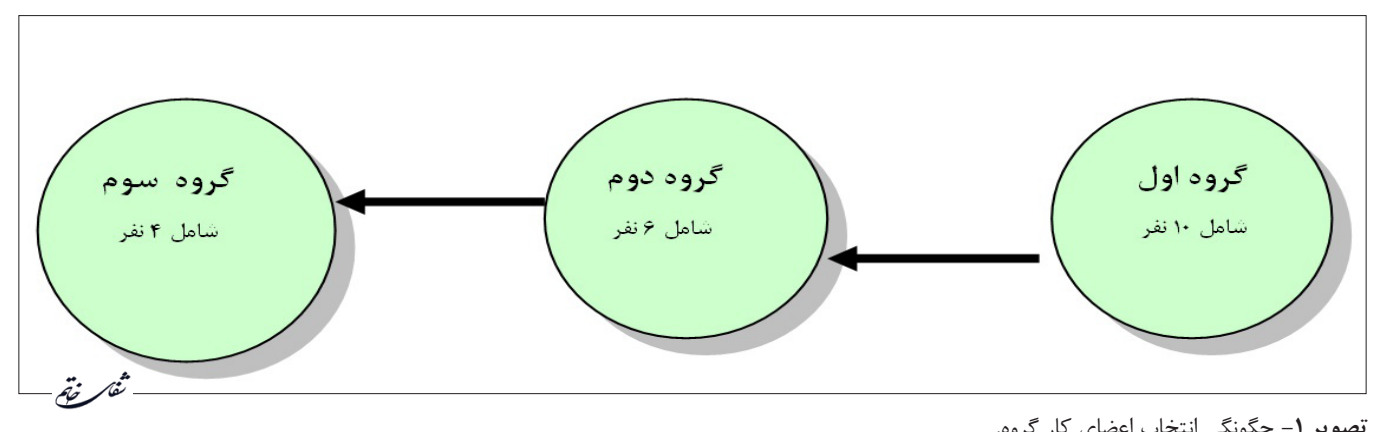

تصوير ا- حهَّونكَى انتخاب اعضاى كار كروه.

\footnotetext{
${ }^{24}$ Rounds

${ }^{25}$ Expert Panel

${ }^{26}$ Panel
} 
در بخش اول يرسشنامه، ليستى از عوامل مؤثر بر استراترى

يافتهها

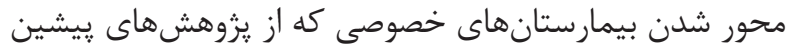

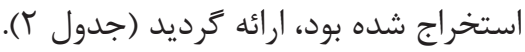

يس از ادغام و طبقه بندى عوامل مندرج در جدول ז، شانزده

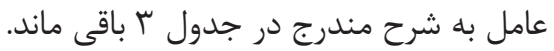

در بخش اول يرسشنامة ياد شده، ياسخكو بايد نظر خود را درباره

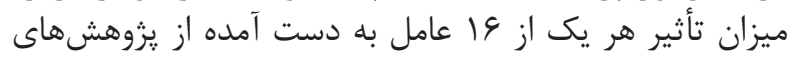

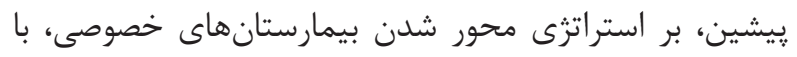

در اين يثوهش، روش دلفى در مجموع در جهار دور به انجام

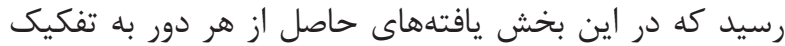
ارائه مىشود.

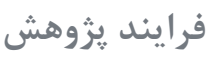

رائه مى شود.

ا. نتايج دور اول روش دلفى مودى

يرسشنامة دور اول دلفى شامل دو بخش به شرح زير بود:

\begin{tabular}{|c|c|c|c|}
\hline عوامل بيشنهادى & عنوان تحقيق & سال انجام تحقيق & 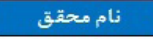 \\
\hline 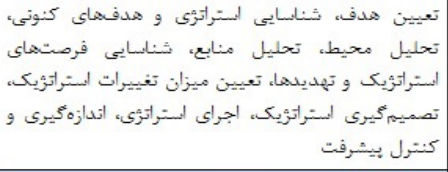 & مديريت: مراحل برنامه ريزى استراتئيك & 1990 & استوتر و همكاران \\
\hline ت ل اختار & شركت فروش محور & १९१४ & اشميت \\
\hline ساختار، منابع، رهبرى & مديريت منابع اتساتى استراترويكى & 19१r & ايزن استات \\
\hline ساختار، منابع & رالهنماى عملى و كوتاه مدت براى الجراى & r. & 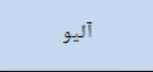 \\
\hline 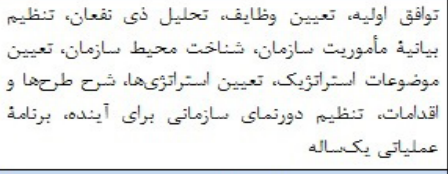 & 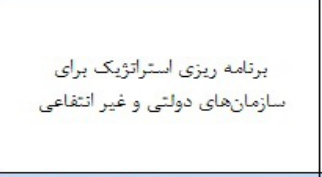 & $r \cdot 11$ & برايسون \\
\hline لماختار، منابع، رهبرى & ههيارتهاى خاموش اجراى استراتثىى & r. & بير \\
\hline 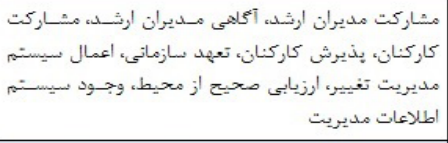 & بريزى استراتثيكى عوامل موثر بر موفقيت ملى برتامه & r.q & حقيقى و همكاران \\
\hline 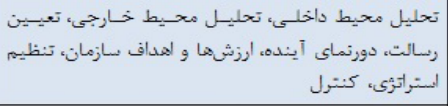 & مديريت الستراتريكى سازمانهاى درماتى & 1990 & دانكن و همكاران \\
\hline 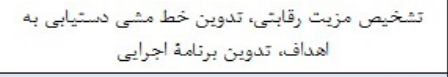 & الستراتوى خوب/الستراتثى بد & $r \cdot 11$ & 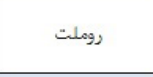 \\
\hline 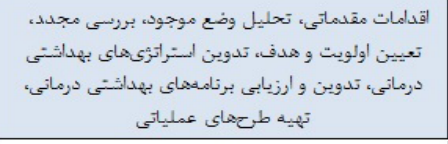 & 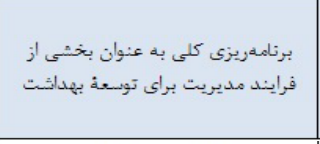 & 1919 & نسازمان تجارت \\
\hline زمان & كفقتار بدون كردار & १११६ & ساتدى لندز \\
\hline ساختار، منابع، رهبرى، عوامل بيش بينى تشـده & اجراى موفقيت آميز تصميمات & 1910 & 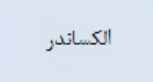 \\
\hline ساختار، فرهنكَ، منابع، ساير عوامل & جرا اجراى برنامهناى استراتريكى با مواجه مىثود؟ & $r \cdot 11$ & كالى و همكاران \\
\hline 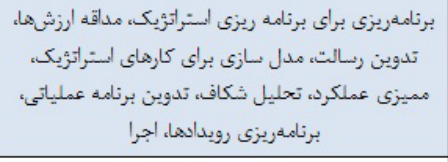 & برتامه ريزى الستراتريكى كاربردى & 1990 & 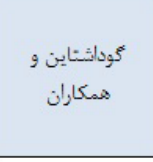 \\
\hline تحليل موقعيت، فرموله كردن و اجراى استراتوى & |مديريت استراتريكى سازمانهاى درماتى & $r \cdots 9$ & ل ليندا و همكاران \\
\hline ساختار، فرهنك، رهبرى & اجراى تصميمات الستراتريكى & १९१४ & 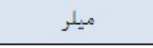 \\
\hline تدوين استراتثى، اجراى الستراتثىى & فرايند استراترى: مفاديمه، زمينهما، & ११९९ & مينتزبرك و ماران \\
\hline 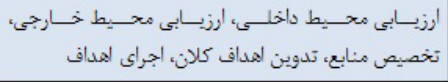 & مديريت استراتريكى جه جيزى است؟ & $r \cdots v$ & ناقى و جن \\
\hline 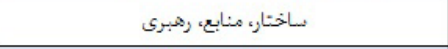 & ساختار، سازمان نيست & 191. & واترمن و همكاران \\
\hline 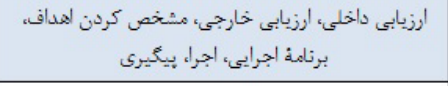 & شناسابي خدمات مناسب قابل عرضه & 1911 & وايتمن \\
\hline 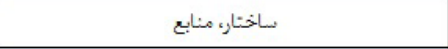 & بلى بين استراتئى و عمل & 19人F & 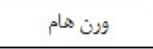 \\
\hline 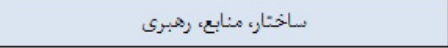 & فرايندماى مديريت منابع اتساتى & 199r & وبسيل \\
\hline 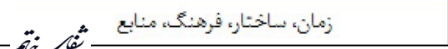 & مواتع اجراى اتربخش استراترى & $r \ldots 4$ & هرى بينياى \\
\hline
\end{tabular}




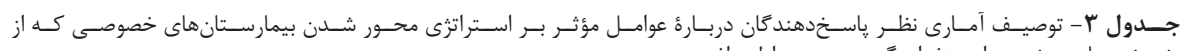

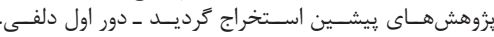

\begin{tabular}{|c|c|c|c|c|}
\hline ترتيب اهميت & انحراف معيار باسخها & ميانكَين باسخها & تعداد باسخها & شرح عامل \\
\hline 1. & $1 / 14$ & T/AT & r. & 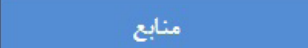 \\
\hline 11 & $1 / r r$ & r/gr & $r \cdot$ & فناورى ييشرفته \\
\hline 1 &.$/ 48$ & f/ar & r. & مأموريت اساسى بيمارستان \\
\hline ir & $1 / r f$ & $r / f r$ & $r \cdot$ & ساختار سازمانى \\
\hline ir & $1 / r 4$ & $r / r$. & $r \cdot$ & مديريت كارآمد \\
\hline$\Delta$ & $\cdot|\lambda|$ & $f / \Delta 1$ & r. & تدوين استر اتثرى \\
\hline \& &.$/ 94$ & F/FY & $r$. & جشم انداز \\
\hline if & $1 / \pi v$ & $r / \cdot \Lambda$ & $r \cdot$ & فرهنغ سازمانى \\
\hline 10 & $1 / 41$ & r/ar & $r \cdot$ & مسئوليتبذيرى اجتماعى \\
\hline 9 & $\cdot / 9 \Delta$ & $4 / .9$ & r. & كنترل و ارزيابى \\
\hline v & .94 & f/rf & $r$. & اجراى استراتزى (دستاور دها) \\
\hline$\wedge$ & $\cdot / 99$ & $f / 1 r$ & r. & 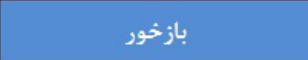 \\
\hline r & $1 /{ }^{\prime} \wedge$ & $r / 9 \Lambda$ & r. & موقعيت بيمارستان در بين رقبا \\
\hline 19 & $1 / \Delta 9$ & $r / \Delta r$ & r. & سيستم اطلاعات مديريت \\
\hline r & $\cdot / \Delta \Delta$ & F/AV & $r \cdot$ & 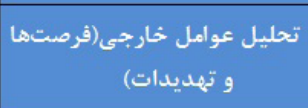 \\
\hline 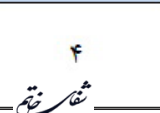 &.$/ 91$ & $f / q 4$ & $r \cdot$ & تحليل عوامل داخلى(قوتها و ضعفام) \\
\hline
\end{tabular}

ياسخ دهند

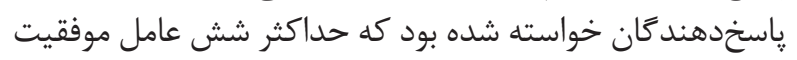

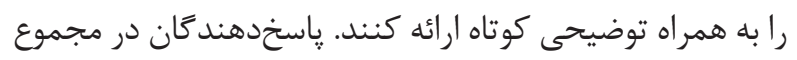

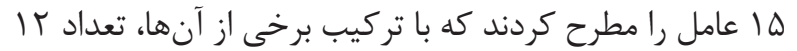

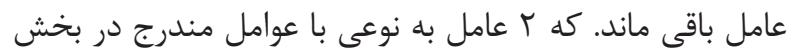

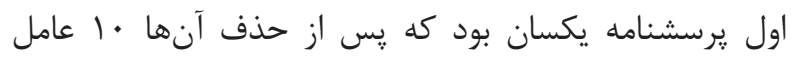

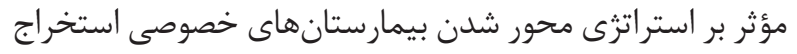

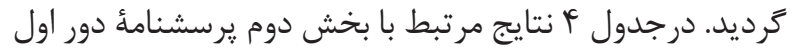

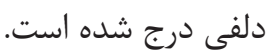

انتخاب يكى از زَينهاي موجود در مقابل آنها اعلام مىكرد.

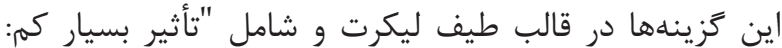

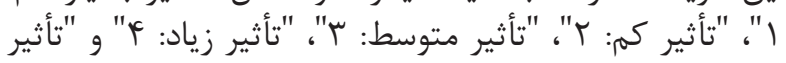

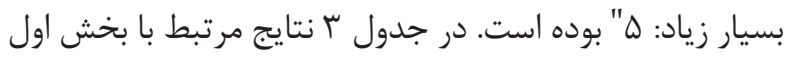

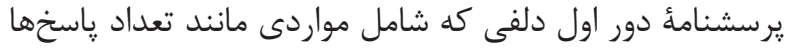

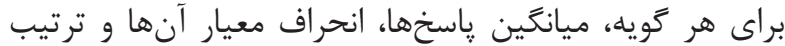

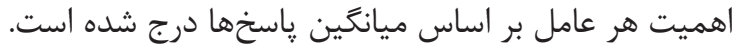
بخش دوم يرسشنامة دور اول روش دلفى به ارائهُ عوامل مؤثرى اختصاص داشت كه در ليست بخش دور روش دلفى موجود نبود، اما از نظر مؤرى

جدول F F ع عامل مؤثر بر استراتثى محور شدن بيمارستانهاى خصوصى.

\begin{tabular}{|c|c|}
\hline عوامل يِيشنهاد شده توسط اعضاى كار تروه & شماره \\
\hline وجود سيستم جانشين يرورى در بيمارستان & 1 \\
\hline شناسايى ارزشهاى مورد تأكيد بيمارستان & $r$ \\
\hline توجه به منظرهاى يهار كانه (مالى، مشتريان، فر ايندها و كاركنان) & r \\
\hline وجود سلامت ادارى و سازملى در بيمارستان & r \\
\hline روحيةُ تحول كرايى در بيمارستان & $\Delta$ \\
\hline وجود سيستم كار آفرينى سازمانى & 9 \\
\hline وجود سيستم مديريت دانش در بيمارستان & v \\
\hline توجه به ارتباط علت و معلولى منظرهاى جههار كانه & $\wedge$ \\
\hline شفاف بودن عملكرد بيمارستان & 9 \\
\hline شناسايى ارزشهاى اسا(مى مؤثر بر عملكرد بيمارستيان. & 1. \\
\hline
\end{tabular}


ترتيب اهميت هر يك از عوامل از نظر تأثير بر استراتزى محور

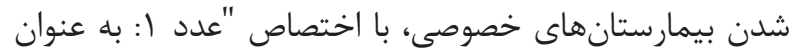

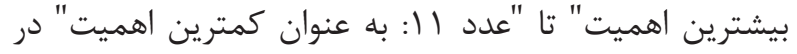

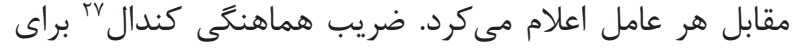

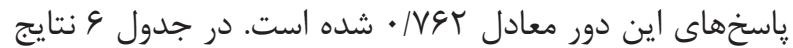
دور سوم دلفى نشان داده شده است. F ا. نتايج دور جههارم روش دلفى

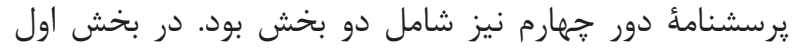

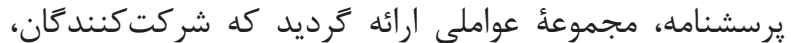

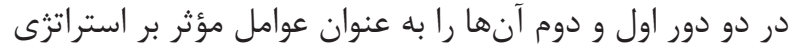

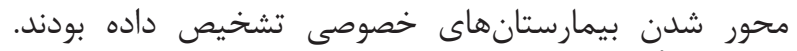

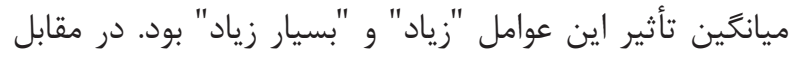

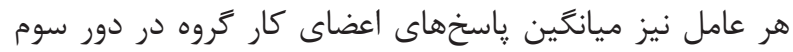

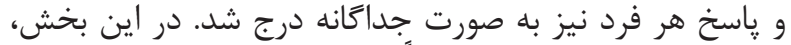

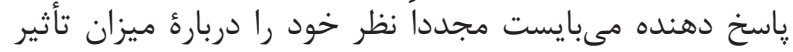

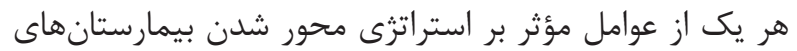

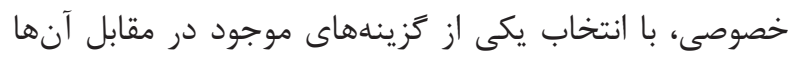

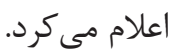

در بخش دوم اين : يرسشنامه، مجموعة عوامل كليدى و مؤثر

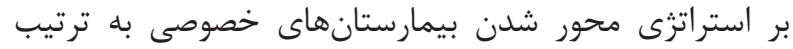

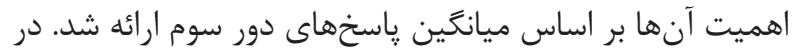

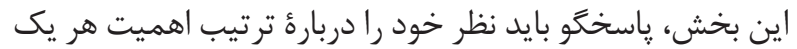

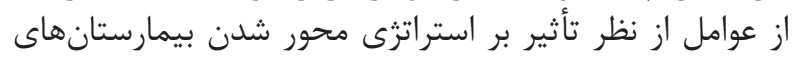

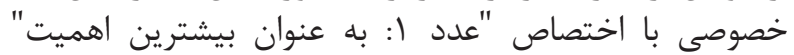

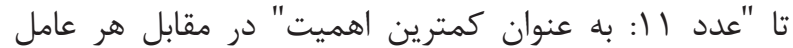

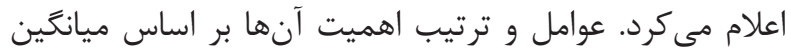

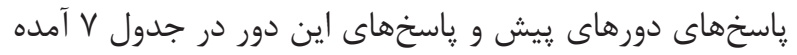

r. نتايج دور دوم روش دلفى

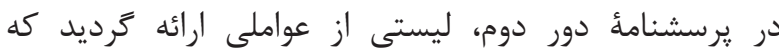
شركت كنند

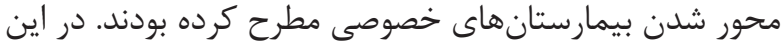

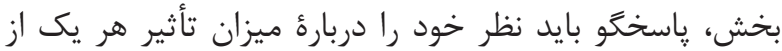

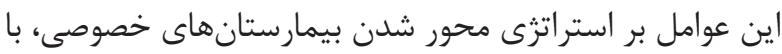

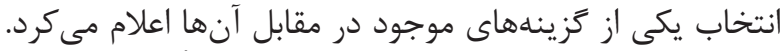

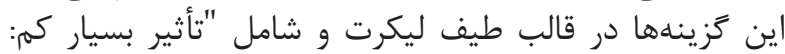

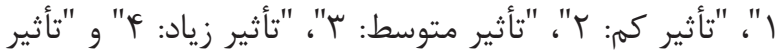

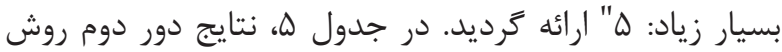

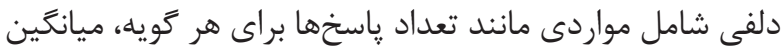

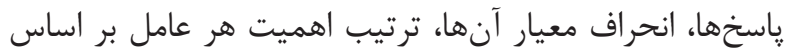

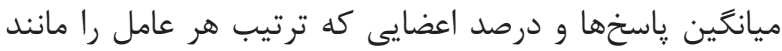
ترتيب گروه تعيين كردهاند، درج شده است داعل r. نتابج دور سوم روش دلفى

يرسشنامdٔ دور سوم دلفى خود شامل دو بخش بود. در بخش

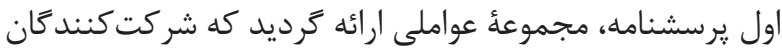

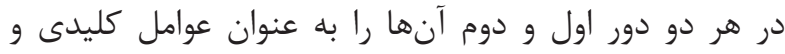

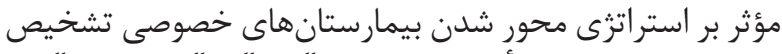

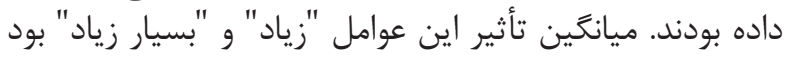

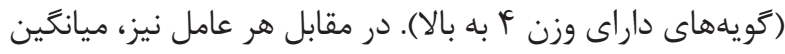

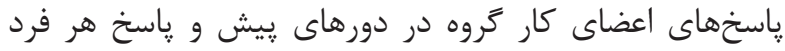

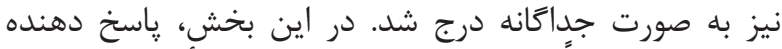

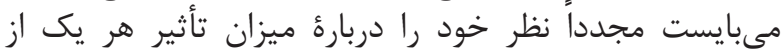

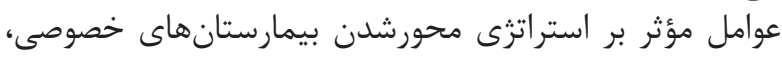

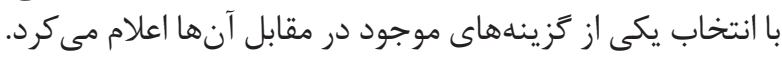
در بخش دوم يرسشنامه، پاسخ دهنده بايد نظر خود را درباره

\begin{tabular}{|c|c|c|c|c|}
\hline ترتيب اهميت & إخراف معيار & ميانكين ياستها & تعداد ياسخها & شرح عامل \\
\hline $1 \cdot$ & $1 / 94$ & $T / T_{T}$ & $r \cdot$ & وجود سيستم جانشين برورى در بيمارستان \\
\hline 1 & $\cdot / 4 \Lambda$ & $4 / 9$. & $r \cdot$ & ارزش ارهاى مديريت بيمارستان \\
\hline r & $\cdot / \Delta F$ & r/AT & $r \cdot$ & 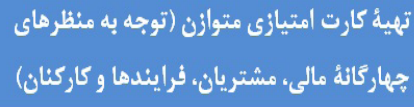 \\
\hline Q & $1 / r$ & r/99 & r. & وجود سلامت ادارى و سازمانى در بيمارستان \\
\hline 9 & $1 / 19$ & $r / 91$ & $r \cdot$ & روحيةٌ تحول ترايى در بيمارستان \\
\hline$\Lambda$ & $1 / \pi \omega$ & r/F & r. & وجود سيستم كار آخرينى سازمانى \\
\hline 9 & $1 / \uparrow \wedge$ & $r / 9 \Lambda$ & $r \cdot$ & وجود سيستم مديريت دانش در بيمارستان \\
\hline r & $\cdot / \Lambda F$ & $f / I V$ & r. & 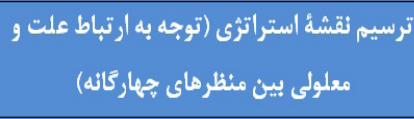 \\
\hline v & $1 / 1 \wedge$ & $r / 90$ & $r \cdot$ & شفاف بودن عملكرد بيمارستان \\
\hline$\ddot{r}$ &.$/ 94$ & f/Ft & r. & إز ارشهاى اسلامى \\
\hline
\end{tabular}

${ }^{27}$ Kendall's coefficient of concordance 


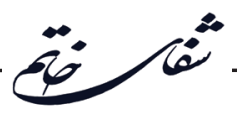

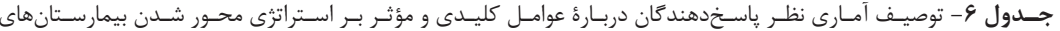

خصوصسى ـ دور سـوم دلفـى توصي

\begin{tabular}{|c|c|c|c|c|}
\hline ترثيب اهميت & انحراف معيار & ميائكين ياسخها & تعداد ياسخها & شرح عامل \\
\hline r & $\cdot / 4$ & FiNT & $r \cdot$ & تهيه كارت امتيازى متوازن \\
\hline 4 & $\cdot / N$ & G/AT & $r$ r. & إرزشهاى مديريت \\
\hline r &.$/ \% 4$ & FiND & $r$ r. & إزاشىهاى اسلامى \\
\hline v & $\cdot V_{D}$ & GRT & $r$ r. & ماموريت اساسى بيمارستان \\
\hline 11 & $\cdot / \Lambda \Lambda$ & $\varphi / 14$ & $r$. & جشم انداز بيمارستان \\
\hline 9 & $\cdot / \mathrm{VA}$ & pirq & $r$. & ت تدوين استراتثى \\
\hline 1. & .190 & $9 / 19$ & $r$. & ترسيم نقشهُ استراتزىى \\
\hline r & .19 & $\varphi(\Delta)$ & $r$ r. & تحليل عوامل داخلى \\
\hline 1 & $\cdot / r \Lambda$ & $\% / 9$. & $r$. & شناسايى دستاور دهاى استراتزيكى (عملكرد) \\
\hline ir &.$/ 91$ & 4.4 & $r$. & كنترل \\
\hline$\Lambda$ & $\cdot / N$ & $p / 4$. & $r$. & 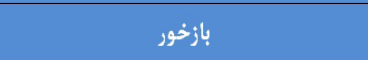 \\
\hline$\dot{\theta}$ & $\cdot N I$ & F/FY & $r$. & تحليل عوامل خارجى \\
\hline
\end{tabular}

براساس جدول شمارة 1 ميانكَين انحراف معيار ياسخهاى

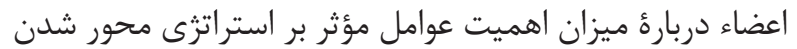

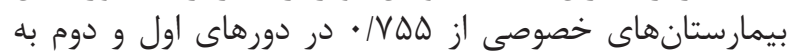

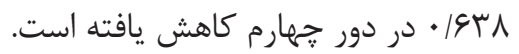

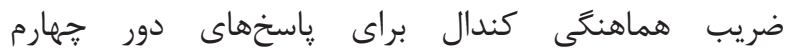

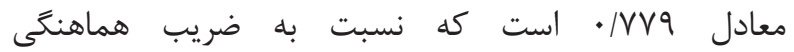

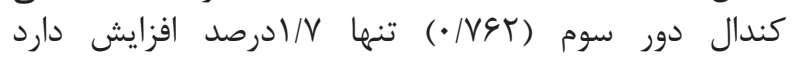

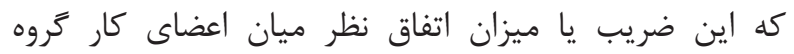

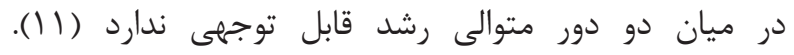

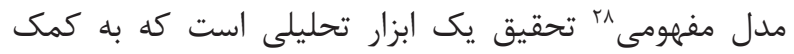

است. ضريب هماهنگى كندال براى پاسخهاى اين دور معادل

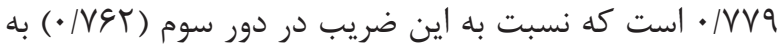
ميزان V/V/ ادرصد افزايش يافته است.

$$
\text { بحث و نتيجه كيرى }
$$

نتايج دورهاى جهار كانهُ روش دلفى نشان مئدهند كاند كه به دلايل

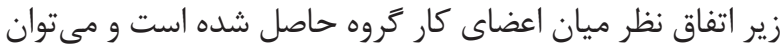

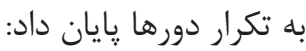

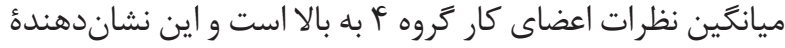

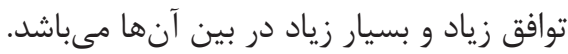

\begin{tabular}{|c|c|c|c|c|}
\hline ترتيب اهميت & انحراف معيار & ميانتين باسخها & تعداد باسخها & شرح عامل \\
\hline 9 & $\cdot / N G$ & $F / r \Lambda$ & $r \cdot$ & تهية كارت امتيازى متوازن \\
\hline r & .19. & $F / \Delta$ & $r \cdot$ & ارزن هاى مديريت \\
\hline$\Delta$ & $\cdot / \mathrm{V}$ & fRt & r. & ارزن لماى اسلامى \\
\hline$r$ & $\cdot|+|$ & $F / \Lambda \mid$ & r. & مأمورت اساسى بيمارستان \\
\hline 4 & $\cdot / \mathrm{r}$ & F/F. & r. & حشم اتداز بيمارستان \\
\hline$v$ & $\cdot / N T$ & F/Tt & $r \cdot$ & تدوين استراتزى \\
\hline$\Lambda$ & $\cdot|N|$ & $p / r q$ & $r \cdot$ & ترسيم نقشهُ استراترى \\
\hline 1 & $\cdot / \pi 4$ & $4 / 91$ & $r$. & تحليل عوامل داخلى \\
\hline 1. & .194 & $4 / 11$ & $r \cdot$ & شناسايى دستاوردهاى استراتريكى (عملكرد) \\
\hline 11 & $\cdot / 19$ & $4 / 11$ & $r \cdot$ & 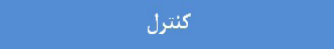 \\
\hline it & .194 & $r / \cdot V$ & $r \cdot$ & بازخور \\
\hline 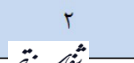 & $\cdot \pi \Delta$ & $F / \wedge F$ & $r \cdot$ & تحليل عوامل خارجى \\
\hline
\end{tabular}




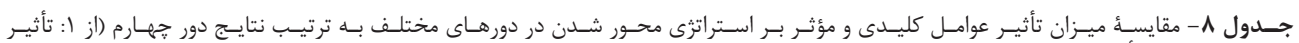

\begin{tabular}{|c|c|c|c|c|c|c|}
\hline \multicolumn{2}{|c|}{ 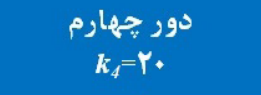 } & \multicolumn{2}{|c|}{ 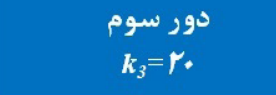 } & \multicolumn{2}{|c|}{ 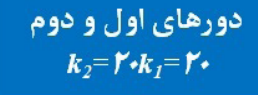 } & \multirow[t]{2}{*}{ عامل } \\
\hline انحراف معيار & ميانعين & انحراف معيار & ميانكين & انحراف معيار & ميانكين & \\
\hline • & $4 / 91$ & $\cdot 19$. & $f / \Delta)$ & .181 & F/GF & تحليل عوامل داخلى \\
\hline$\cdot / \pi \Delta$ & $F / \Lambda F$ & $\cdot / \mathrm{VI}$ & f/fF & $\cdot / \Delta \Delta$ & $F / \wedge V$ & تحليل عوامل خارجى \\
\hline .19. & $\boldsymbol{r} / \Delta$. & $\cdot / \mathrm{V}$ & f/At & $\cdot / 4 \Lambda$ & $r / q$. & ارزنشهاى مديريت بيمارستان \\
\hline$\cdot / \mathrm{V} \cdot$ & R/At & 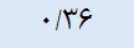 & $f / \wedge \Delta$ &.$/ 94$ & fift & ارزثهاى اسلامى \\
\hline$\cdot|f|$ & $F / 1)$ & $\cdot / V \Delta$ & ( & $\cdot / 49$ & $r / 9 r$ & مأموريت اساسى بيمارستان \\
\hline$\cdot / \mathrm{V}$ & $\varphi / c$. & $\cdot \mid \Lambda \Lambda$ & $F / 1 r$ & $\cdot / 97$ & F/ET & جشم انداز بيمارستان \\
\hline$\cdot / V T$ & p/rt & $\cdot / \mathrm{VA}$ & $p / r q$ & $\cdot|\Lambda|$ & $F / \Delta)$ & تدوين استراترى \\
\hline$\cdot / \mathrm{VI}$ & $r / r q$ & $\cdot 190$ & $4 / 19$ & $\cdot \mid \Lambda F$ & $F / l V$ & ترسيم نقشه استراتوى \\
\hline$\cdot / V 4$ & $F / r \Lambda$ & $\cdot / 4$ & F/AT & $\cdot / D F$ & F/AT & تهيذُ كارت امتيازى متوازن \\
\hline$\cdot 199$ & $\varphi / 11$ & $\cdot / r \Lambda$ & $r / q$. &.$/ 94$ & 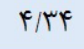 & اجراى استراتُىى( دستاوردها) \\
\hline$\cdot / \wedge \&$ & $4 / 11$ & .191 & $\varphi / .9$ &.$/ 9 \Delta$ & $\boldsymbol{f} / \cdot 9$ & كنترل \\
\hline$\cdot 194$ & $r / \cdot v$ & $\cdot / \mathrm{V}$ & $\boldsymbol{\varphi} / \mathrm{r}$. & $\cdot 199$ & $F / 1 \pi$ & بازخور \\
\hline .941 & & . & & $\cdot / V \Delta \Delta$ & & ميانكين انحراف معيارها \\
\hline
\end{tabular}

به هدف فوق، از روش دلفى كه يكى از روشهاى تحقيق كيفى

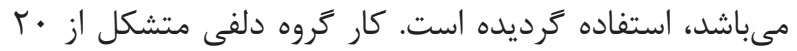

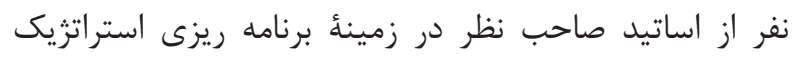

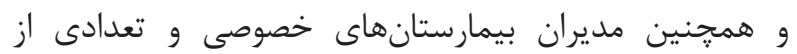

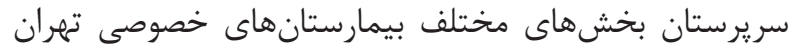

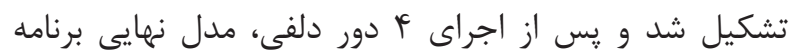

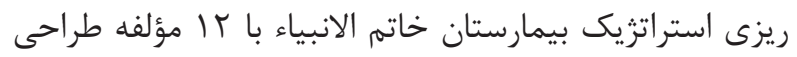

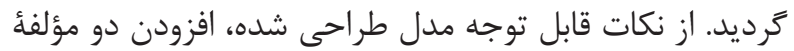

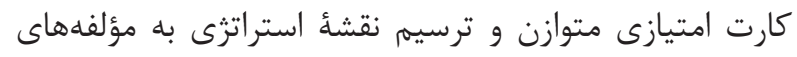

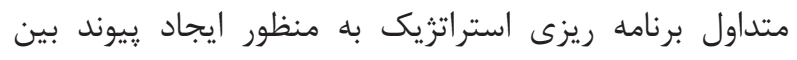

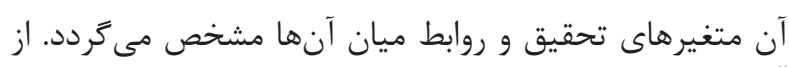

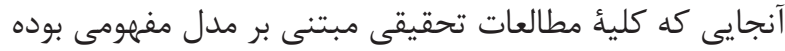

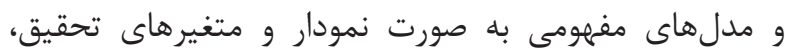

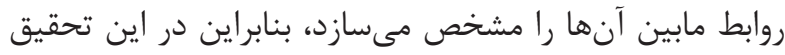

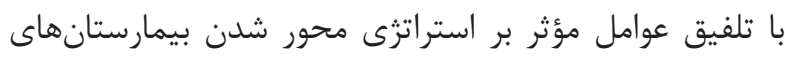

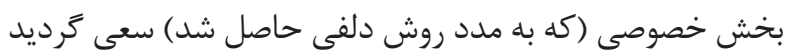

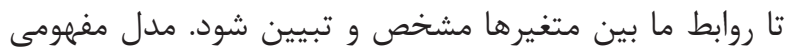

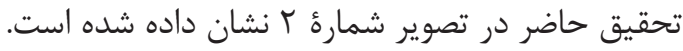
هدف تحقيق حاضر اين بود تا مدل برنامه ريزى استراتزيك

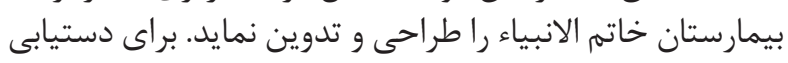

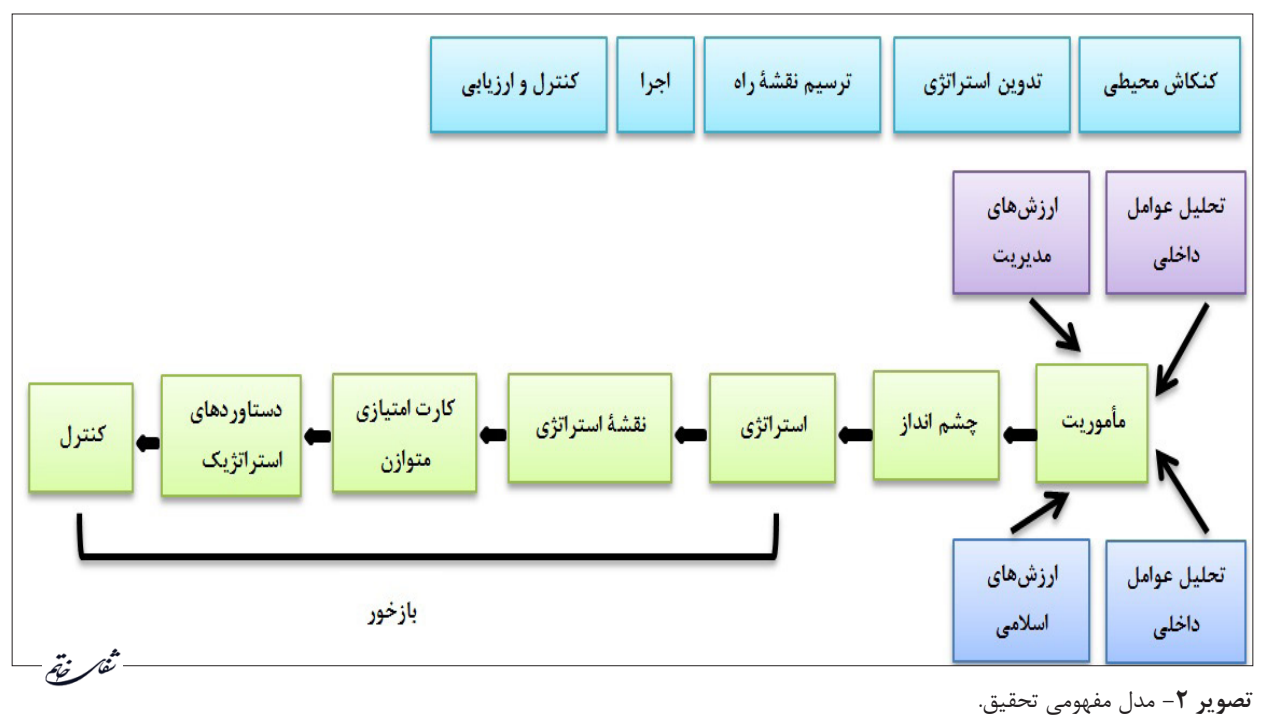


تدوين استراتثى و اجراى استراترى ييوند ايجاد مى كند، لذا بهاء

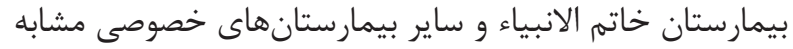

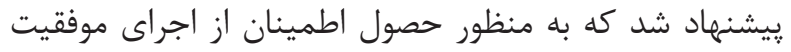
آميز استراترىهاى تدوين شده از اين ابزار استفاده نمايند. r. از آنجايى كه ترسيم نقشأ استراترى و مشخص نمودن روابط

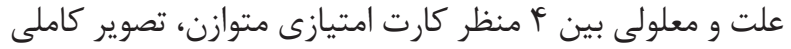

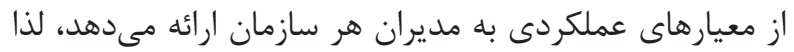

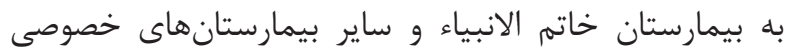

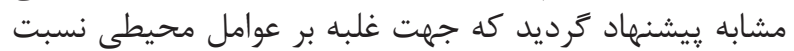

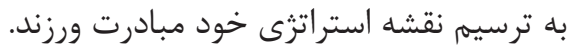

1. Gamble J, Thompson A, Peteraf M. Essentials of Strategic Management: The Quest for Competitive Advantage. $4^{\text {th }}$ ed. McGraw-Hill Education, 2 Penn Plaza, New York. 2014.

2. Dess GG, Lumpkin T, Eisner A, McNamara G. Strategic Management: Text and Cases. $7^{\text {th }}$ ed. McGrawHill Education, 2 Penn Plaza, New York. 2013.

3. Hitt MA, Ireland RD, Hoskisson RE. Strategic Management: Concepts and Cases: Competitiveness and Globalization. 11 ${ }^{\text {th }}$ ed. Cengage Learning. 2014.

4. Rothaermel F. Strategic Management: Concepts. $2^{\text {th }}$ ed. McGraw-Hill Education, 2 Penn Plaza, New York. 2014

5. Pearce J, Robinson R. Strategic Management. $13^{\text {th }}$ ed. McGraw-Hill Education, 2 Penn Plaza, New York. 2012

6. Hill CWL, Jones GR. Strategic Management: An Integrated Approach. 10 $0^{\text {th }}$ ed. Cengage Learning. 2012.
تدوين استراتثى و اجراى آن مى باشد. در يايان بر رعايت موارد

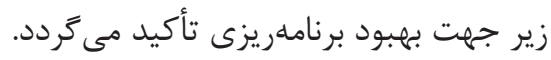

ا. از آنجايى كه امروزه عملكرد سازمانها طبق معيار كارت

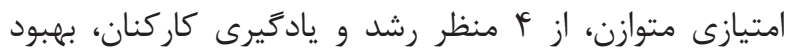

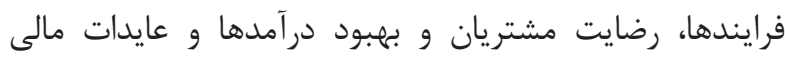

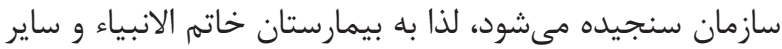

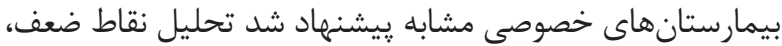

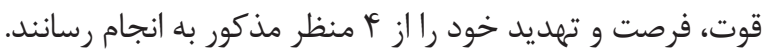

ז. از آنجايى كه كارت امتيازى متوازن، ابزارى است كه بين مرحلئ

7. Wheelen TL . Concepts in Strategic Management and Business. 14 ${ }^{\text {th }}$ edition. Prentice Hall. 2014.

8. McArthur JA. Planning for Strategic Communication: A workbook for applying social theory to professional practice. Create Space Independent Publishing Platform. 2014.

9. Kolivand P. Investigation and selection of appropriate strategic plannig model for privates hospital in Tehran, Iran: a study in Khatam Alanbia Hospital. M.Sc thesis. Tehran. Industrial Management Institute, Management department. 2010.

10. Sarlak MA, Seyed Javadin R, Nejatbakhsh Isfahani A, Viseh A. Identifying the Aspects of Ideal and Spiritual Based Organization in Iran Supreme Education (Islamic Approach). Journal of the Islamic University. 2012; 4: 355-76.

11. Schmidt J. The case of the sales-driven company. J Bus Strategy. 1994; 15(5): 17-20. 